$$
\begin{gathered}
\text { 우리나라 성인의 총 지방 및 지방산 섭취량 평가: } \\
\text { 2016-2017년 국민건강영양조사 자료를 활용하여 } \\
\text { 송수진 }{ }^{1)} \text { - 심재은2)† } \\
\text { 1)한남대학교 식품영양학과, 교수, }{ }^{2} \text { 대전대학교 식품영양학과, 교수 }
\end{gathered}
$$

\title{
Evaluation of Total Fat and Fatty Acids Intakes in the Korean Adult Population using Data from the 2016-2017 Korea National Health and Nutrition Examination Surveys
}

\author{
SuJin Song ${ }^{1)}$, Jae Eun Shim ${ }^{2 \dagger}$ \\ ${ }^{1)}$ Department of Food and Nutrition, Hannam University, Daejeon, Korea, Professor \\ ${ }^{2)}$ Department of Food and Nutrition, Daejeon University, Daejeon, Korea, Professor
}

\section{${ }^{\dagger}$ Corresponding author Jae Eun Shim \\ Department of Food and Nutrition, Daejeon University, 62 Daehak-ro, Dong-gu, Daejeon, 34520, South Korea. \\ Tel: (042) 280-2469 \\ Fax: (042) 280-2468 \\ E-mail: jshim@dju.kr \\ Acknowledgments \\ This work was supported by the National Research Foundation of Korea (NRF) grant funded by the Korea government (MSIT; Ministry of Science and ICT) (Grant No. 2016R1D1A1B 03931820 and 2017R1C1 B5017637).}

Received: May 18, 2019 Revised: June 10, 2019 Accepted: June 10, 2019

\section{ABSTRACT}

Objectives: This study evaluated dietary intakes of total fat and fatty acids among the Korean adult population.

Methods: This cross-sectional study used the 2016-2017 Korea National Health and Nutrition Examination Survey data. A total of 10,772 subjects aged $\geq 19 \mathrm{y}$ for which dietary data were available were selected. Data pertaining to energy and nutrient intakes were obtained by a $24-\mathrm{h}$ recall method. Total fat and fatty acids intakes were evaluated based on the Acceptable Macronutrient Distribution Ranges (AMDR) of 2015 Dietary Reference Intakes for Koreans by sex and age groups. All statistical analyses accounted for the complex sampling design effect and sampling weights.

Results: The mean intakes of energy and total fat were 1,952 kcal (95\% CI: $1928-$ $1977)$ and $46.1 \mathrm{~g}(45.2-47.1)$, respectively, and about $21 \%$ of the energy was obtained from fat in this study population $(21.7 \%$ in men and $20.2 \%$ in women). The mean percentages of energy from saturated, monounsaturated, and polyunsaturated fatty acids were $6.4 \%, 6.7 \%$, and $5.2 \%$, respectively. About $18 \%$ of adults exceeded the AMDR for fat $(30 \%$ of energy), whereas $37.6 \%$ exceeded the AMDR for saturated fatty acids ( $7 \%$ of energy). The proportions of subjects who consumed more than the AMDR for fat and saturated fatty acids decreased across age groups in both sexes. Among young adults (19-29 y), about $63 \%$ of the subjects obtained $\geq 7 \%$ of their energy from saturated fatty acids. About $61 \%$ of older adults obtained less than $15 \%$ of their energy from total fat.

Conclusions: Increased intake of fat energy was prominent in saturated fatty acids. Our findings suggest current information on total fat and fatty acids intakes in Korean adults and can be used to provide dietary guidelines for the improvement of public health.

Korean J Community Nutr 24(3): 223 231, 2019

KEY WORDS dietary fats, saturated fatty acids, Korean adults, KNHANES

This is an Open-Access article distributed under the terms of the Creative Commons Attribution Non-Commercial License (http:// creativecommons.org/licenses/by-nc/3.0) which permits unrestricted non-commercial use, distribution, and reproduction in any medium, provided the original work is properly cited. 


\section{서 론}

만성질환의 이환 증가는 의료비 지출에 따른 경제적 부담 을 가중시키고 활동 제한과 조기 사망의 주요 원인으로서 삶 의 질을 위협하므로 이에 대한 예방과 관리는 전세계적인 관 심사이다. 경제발전에 따라 삶의 수준이 높아지면서 식품의 유용성과 식품 종류의 다양성 확대, 질병예방과 건강증진을 위한 보건서비스의 접근성 증가와 같은 긍정적인 변화가 있 었음에도 불구하고, 부적절한 식사 섭취 패턴, 신체활동 감 소, 흡연과 같은 건강유해행위로 인해 만성질환의 이환은 증 가하고 있다. 특히, 식품섭취패턴에 있어서는 포화지방산 함 량이 높으며 에너지 밀도가 높은 식품과 단맛을 선호하는 부 적절한 식품선택이 현재와 같은 만성질환의 건강문제에 기 여하였다고 인식되고 있다[1].

질병관리본부에 의하면 우리나라는 비감염성 만성질환으 로 인한 사망과 질병 부담이 매우 높아서, 사망원인 상위 10 위 중 7 개가 만성질환이며 전체 사망의 $80.8 \%$ 를 차지하고 있다[2]. 또한, 노인인구가 증가됨에 따라 만성질환의 사회 적 부담은 가중될 것으로 예측되므로 만성질환의 예방과 관 리의 필요성은 더욱 높아지고 있다 [3]. 이와 함께 우리나라 의 지난 10 년간 사망원인 추이가 주의를 끄는 것은 심장질환 과 뇌혈관질환의 사망원인 순위가 변동하였다는 것이다. 뇌 혈관 질환으로 인한 사망은 꾸준히 감소하는 반면 심장질환 으로 인한 사망은 증가하여 지난 2012년 이후 심장질환으로 인한 사망이 뇌혈관질환으로 인한 사망을 앞서게 되었다 [3]. 이처럼 만성질환으로 인한 사회적 부담이 증가하고 있음에도 불구하고 이를 예방하기 위한 건강생활습관의 실천은 개선되 지 않고 있다. 동 보고서에서 지적하는 바와 같이 2007년과 비교하였을 때 흡연율만 다소 감소하였을 뿐 걷기 실천율은 감소했고, 에너지 과잉섭취자와 고위험 음주율은 증가한 상 태이다 [2].

또한 주요 사망원인의 변화에 있어서 포화지방산 섭취 증 가와 같은 부적절한 섭취패턴 등의 환경적 요인이 영향을 미 치고 있는 것으로 보인다. 최근 우리나라의 포화지방산 섭취 추이에 관한 보고에 의하면, 평균적인 섭취수준은 서구사회 에 비해 상대적으로 낮은 수준이나 섭취 수준이 지속적으로 증가하는 양상이다 [4-8]. 이는 동물성 식품 섭취 증가와 같 은 식생활의 변화에 따른 결과로, 심혈관계질환의 위험을 높 이는 고콜레스테롤혈증의 증가 양상이나 심장질환으로 인한 사망 순위의 증가도 이와 무관하지 않은 것으로 사료된다. 포 화지방산의 섭취가 혈중 LDL-콜레스테롤 수준을 증가시킴 으로써 관상심장질환의 잠재적인 위험요인으로 제시된 이
래, 에너지를 제공하는 다량 영양소 간 심혈관계질환의 상대 적인 위험에 관한 많은 연구가 이루어졌다 [9-13]. 최근의 체계적 고찰연구에서는 에너지 섭취수준을 통제한 상태에서 식사의 포화지방산이 탄수화물과 불포화지방산에 비해 혈중 $\mathrm{LDL}$-콜레스테롤 수준을 상승시키는 것으로 분석된 바 있 다 [14].

이에 본 연구는 국민건강영양조사의 최신 자료인 제7기 자 료를 이용하여 총 지방 및 지방산 종류별 섭취현황을 분석하 고, 선행연구를 통해 보고된 우리나라 성인의 지방산 섭취 추 이의 최근 동향을 확인하기 위해 수행되었다. 나아가 본 연 구 결과가 우리나라 만성질환 현황에 의미하는 바를 고찰하 여 향후 만성질환의 건강위험 관리전략 수립에 있어 신중한 방향성 설정을 위한 근거자료를 마련하고자 하였다.

\section{연구 대상 및 방법}

\section{1. 연구 자료 및 대상자}

본 연구에서는 제7기 1, 2차년도 (2016-2017년) 국민 건강영양조사 자료를 활용하였다. 국민건강영양조사는 우리 나라 국민의 영양 및 건강 상태를 파악하기 위해 시행하는 전 국 규모의 조사로서, 질병관리본부에서 매년 수행하고 있다. 국민건강영양조사는 층화집락표본설계를 이용하여 표본을 추출하며, 건강설문조사, 검진조사, 영양조사로 구성되어 있 다. 조사에 관한 구체적인 정보는 이전 문헌에 자세히 기술 되어 있다[15]. 본 연구에 포함된 대상자는 2016-2017년 국민건강영양조사의 영양조사에 참여한 19 세 이상 대상자 중, 임신부와 수유부, 에너지 섭취량이 1 백분위수 미만 또 는 99 백분위수 초과하는 자를 제외한 뒤 총 10,772 명으로 선정되었다. 대상자는 연령에 따라 크게 19-29세, 30-49 세, 50-64세, 65세 이상으로 구분하였다. 성별 및 연령 그 룹에 따른 대상자 분포는 Table 1 과 같다. 국민건강영양조 사는 국가가 직접 공공복리를 위해 수행하는 연구에 해당하 여 연구윤리심의위원회 심의를 받지 않고 수행되었다.

\section{2. 식사 변수}

본 연구에서는 국민건강영양조사의 영양조사 중 1 일의 24 시간 회상법을 통해 얻어진 개인별 에너지 및 영양소 섭취량 자료를 활용하였다. 24 시간 회상 조사는 검진조사를 완료하 고 약 1 주일 후, 영양조사팀이 가구를 방문하여 개인별 면접 방법으로 수행되었다. 에너지 섭취량은 1일 섭취하는 $\mathrm{kcal}$ 단위로 제시하였고, 다량영양소는 섭취량 $(\mathrm{g})$ 과 함께 에너지 섭취량에 대한 각 다량영양소로부터 얻는 에너지 섭취 비율 (\%)을 계산하여 제시하였다. 또한 각 지방산 종류별 (포화, 
Table 1. Study subjects by sex and age group

\begin{tabular}{ccccccc}
\hline & \multicolumn{2}{c}{ Total $(\mathrm{n}=10,772)$} & \multicolumn{2}{c}{ Men $(\mathrm{n}=4,615)$} & \multicolumn{2}{c}{ Women $(\mathrm{n}=6,157)$} \\
\cline { 2 - 7 } & $\mathrm{n}$ & $\%$ & $\mathrm{n}$ & $\%$ & $\mathrm{n}$ & $\%$ \\
\hline $19-29 \mathrm{y}$ & 1,204 & 17.2 & 542 & 18.1 & 662 & 16.3 \\
$30-49 \mathrm{y}$ & 3,630 & 38.1 & 1,512 & 39.8 & 2,118 & 36.3 \\
$50-64 \mathrm{y}$ & 3,011 & 28.0 & 1,265 & 27.8 & 1,746 & 28.1 \\
$\geq 65 \mathrm{y}$ & 2,927 & 16.8 & 1,296 & 14.4 & 1,631 & 19.2 \\
\hline
\end{tabular}

단일불포화, 다중불포화, $n-3$ 계, $n-6$ 계 지방산) 섭취량과 에너지 섭취 비율도 제시하였다. 한국인 영양소 섭취기준의 에너지 적정 비율에 따라 총 지방 및 포화지방산 섭취를 평 가하였다[16]: 총 지방으로부터 얻는 에너지 비율이 $15 \%$ 미만, 15-30\%, 30\% 초과인 경우로 분류하였고, 포화지방 산으로부터 얻는 에너지 비율이 $7 \%$ 미만과 $7 \%$ 이상인 경 우로 나누었다.

\section{3. 통계 분석}

본 연구의 모든 통계 처리는 SAS 9.4 (Statistical Analysis System version 9.4, SAS Institute, Cary, $\mathrm{NC}$ ) 소프트웨어를 이용하였다. 국민건강영양조사는 층화집 락표본설계를 이용하였음에 따라 복합표본설계 요소를 반영 하여 분석하였다. 에너지 및 영양소 섭취량 및 각 영양소의 에너지 섭취 비율은 성별 및 연령 그룹에 따라 평균 및 $95 \%$

Table 2. Intakes of total fat and fatty acids by sex and age group ${ }^{a}$

\begin{tabular}{|c|c|c|c|c|c|c|c|c|c|c|}
\hline \multirow{3}{*}{$\frac{\text { Age group }}{\geq 19 y}$} & \multirow{4}{*}{$\begin{array}{l}\text { Energy \& nutrient } \\
\text { Total fat }(\mathrm{g})\end{array}$} & \multicolumn{3}{|c|}{ Total } & \multicolumn{3}{|c|}{ Men } & \multicolumn{3}{|c|}{ Women } \\
\hline & & mean & \multicolumn{2}{|c|}{$95 \% \mathrm{Cl}^{\mathrm{b}}$} & mean & \multicolumn{2}{|c|}{$95 \% \mathrm{Cl}$} & \multicolumn{3}{|c|}{$95 \% \mathrm{Cl}$} \\
\hline & & \multicolumn{3}{|c|}{$(n=10,772)$} & \multicolumn{3}{|c|}{$(n=4,615)$} & \multicolumn{3}{|c|}{$(n=6,157)$} \\
\hline & & 46.1 & 45.2 & 47.1 & 53.9 & 52.6 & 55.2 & 38.3 & 37.4 & 39.2 \\
\hline & SFA (g) & 14.2 & 13.8 & 14.5 & 16.5 & 16.1 & 16.9 & 11.8 & 11.5 & 12.1 \\
\hline & MUFA (g) & 14.8 & 14.5 & 15.2 & 17.5 & 17.0 & 18.0 & 12.1 & 11.8 & 12.4 \\
\hline & PUFA (g) & 11.3 & 11.0 & 11.5 & 13.0 & 12.7 & 13.4 & 9.5 & 9.3 & 9.7 \\
\hline & n-3 FA (g) & 1.7 & 1.7 & 1.8 & 2.0 & 1.9 & 2.0 & 1.5 & 1.5 & 1.6 \\
\hline & n-6 FA (g) & 9.5 & 9.3 & 9.7 & 11.1 & 10.8 & 11.4 & 8.0 & 7.8 & 8.2 \\
\hline & Energy (kcal) & $1,952.5$ & $1,928.2$ & $1,976.8$ & $2,264.0$ & $2,230.9$ & $2,297.0$ & $1,640.0$ & $1,618.1$ & $1,661.9$ \\
\hline & $\%$ carbohydrate & 64.0 & 63.7 & 64.4 & 62.7 & 62.3 & 63.2 & 65.3 & 64.9 & 65.8 \\
\hline & $\%$ protein & 15.0 & 14.9 & 15.1 & 15.6 & 15.4 & 15.8 & 14.4 & 14.3 & 14.6 \\
\hline & $\%$ fat & 20.9 & 20.7 & 21.2 & 21.7 & 21.3 & 22.0 & 20.2 & 19.9 & 20.6 \\
\hline & $\%$ SFA & 6.4 & 6.3 & 6.5 & 6.6 & 6.5 & 6.8 & 6.2 & 6.1 & 6.4 \\
\hline & $\%$ MUFA & 6.7 & 6.6 & 6.8 & 7.0 & 6.8 & 7.1 & 6.4 & 6.2 & 6.5 \\
\hline & $\%$ PUFA & 5.2 & 5.1 & 5.2 & 5.3 & 5.2 & 5.4 & 5.0 & 4.9 & 5.1 \\
\hline & $\% n-3 F A$ & 0.8 & 0.8 & 0.8 & 0.8 & 0.8 & 0.8 & 0.8 & 0.8 & 0.8 \\
\hline \multirow{17}{*}{$19-29 y$} & $\% n-6 F A$ & 4.3 & 4.3 & 4.4 & 4.5 & 4.4 & 4.5 & 4.2 & 4.1 & 4.3 \\
\hline & & \multicolumn{3}{|c|}{$(n=1,204)$} & \multicolumn{3}{|c|}{$(n=542)$} & \multicolumn{3}{|c|}{$(n=662)$} \\
\hline & Total fat (g) & 60.8 & 58.0 & 63.5 & 67.8 & 63.7 & 71.9 & 52.9 & 49.8 & 56.1 \\
\hline & SFA (g) & 19.7 & 18.7 & 20.6 & 21.6 & 20.3 & 22.9 & 17.5 & 16.3 & 18.8 \\
\hline & MUFA (g) & 20.3 & 19.3 & 21.3 & 22.9 & 21.4 & 24.5 & 17.3 & 16.2 & 18.4 \\
\hline & PUFA (g) & 13.4 & 12.7 & 14.1 & 15.1 & 14.1 & 16.1 & 11.6 & 10.8 & 12.4 \\
\hline & n-3 FA (g) & 1.7 & 1.6 & 1.8 & 1.9 & 1.7 & 2.0 & 1.4 & 1.3 & 1.5 \\
\hline & n-6 FA (g) & 11.7 & 11.1 & 12.4 & 13.2 & 12.3 & 14.1 & 10.1 & 9.4 & 10.8 \\
\hline & Energy (kcal) & $2,050.1$ & $1,990.8$ & $2,109.3$ & $2,312.8$ & $2,224.4$ & $2,401.2$ & $1,757.9$ & $1,692.6$ & $1,823.1$ \\
\hline & $\%$ carbohydrate & 57.6 & 56.8 & 58.4 & 57.3 & 56.1 & 58.4 & 58.0 & 57.0 & 59.0 \\
\hline & $\%$ protein & 15.8 & 15.5 & 16.1 & 16.3 & 15.8 & 16.8 & 15.3 & 14.9 & 15.7 \\
\hline & $\%$ fat & 26.6 & 25.9 & 27.3 & 26.5 & 25.5 & 27.5 & 26.7 & 25.9 & 27.6 \\
\hline & $\%$ SFA & 8.7 & 8.4 & 8.9 & 8.5 & 8.1 & 8.9 & 8.8 & 8.5 & 9.2 \\
\hline & $\%$ MUFA & 8.8 & 8.5 & 9.1 & 8.9 & 8.5 & 9.3 & 8.7 & 8.4 & 9.1 \\
\hline & $\%$ PUFA & 5.9 & 5.7 & 6.1 & 5.9 & 5.6 & 6.2 & 5.9 & 5.6 & 6.2 \\
\hline & $\% n-3 F A$ & 0.7 & 0.7 & 0.8 & 0.7 & 0.7 & 0.8 & 0.7 & 0.7 & 0.8 \\
\hline & $\% n-6 F A$ & 5.1 & 5.0 & 5.3 & 5.1 & 4.9 & 5.4 & 5.1 & 4.9 & 5.4 \\
\hline
\end{tabular}


226 - 우리나라 성인의 지방산 섭취 평가

Table 2. continued

\begin{tabular}{|c|c|c|c|c|c|c|c|c|c|c|}
\hline \multirow[b]{2}{*}{ Age group } & \multicolumn{4}{|c|}{ Total } & \multicolumn{3}{|c|}{ Men } & \multicolumn{3}{|c|}{ Women } \\
\hline & Energy \& nutrient & mean & \multicolumn{2}{|c|}{$95 \% \mathrm{Cl}^{\mathrm{b}}$} & mean & \multicolumn{2}{|c|}{$95 \% \mathrm{Cl}$} & \multicolumn{3}{|c|}{$95 \% \mathrm{Cl}$} \\
\hline \multirow[t]{16}{*}{$30-49 y$} & & \multicolumn{3}{|c|}{$(n=3,630)$} & \multicolumn{3}{|c|}{$(n=1,512)$} & \multicolumn{3}{|c|}{$(n=2,118)$} \\
\hline & Total fat(g) & 52.7 & 51.3 & 54.1 & 60.8 & 58.9 & 62.8 & 43.7 & 42.4 & 45.0 \\
\hline & SFA (g) & 16.2 & 15.7 & 16.7 & 18.7 & 18.0 & 19.4 & 13.5 & 13.1 & 14.0 \\
\hline & MUFA (g) & 17.1 & 16.6 & 17.7 & 20.0 & 19.3 & 20.7 & 14.0 & 13.5 & 14.5 \\
\hline & PUFA (g) & 12.6 & 12.3 & 13.0 & 14.5 & 14.0 & 15.0 & 10.6 & 10.2 & 10.9 \\
\hline & n-3 FA (g) & 1.8 & 1.7 & 1.8 & 2.0 & 1.9 & 2.1 & 1.6 & 1.5 & 1.6 \\
\hline & n-6 FA (g) & 10.8 & 10.5 & 11.1 & 12.5 & 12.0 & 12.9 & 9.0 & 8.7 & 9.3 \\
\hline & Energy (kcal) & $2,087.4$ & $2,051.4$ & 2123.4 & $2,415.9$ & $2,369.0$ & $2,462.8$ & $1,726.4$ & $1,694.5$ & $1,758.3$ \\
\hline & $\%$ carbohydrate & 61.4 & 60.9 & 61.8 & 60.4 & 59.8 & 61.0 & 62.5 & 61.9 & 63.0 \\
\hline & $\%$ protein & 15.6 & 15.4 & 15.7 & 16.0 & 15.8 & 16.3 & 15.1 & 14.9 & 15.3 \\
\hline & $\%$ fat & 23.0 & 22.7 & 23.4 & 23.6 & 23.1 & 24.1 & 22.4 & 22.0 & 22.9 \\
\hline & $\%$ SFA & 7.1 & 6.9 & 7.2 & 7.2 & 7.0 & 7.4 & 7.0 & 6.8 & 7.2 \\
\hline & $\%$ MUFA & 7.5 & 7.3 & 7.6 & 7.7 & 7.5 & 7.9 & 7.2 & 7.0 & 7.3 \\
\hline & $\%$ PUFA & 5.6 & 5.4 & 5.7 & 5.7 & 5.5 & 5.8 & 5.4 & 5.3 & 5.6 \\
\hline & $\%$ n-3 FA & 0.8 & 0.8 & 0.8 & 0.8 & 0.8 & 0.8 & 0.8 & 0.8 & 0.8 \\
\hline & $\%$ n-6 FA & 4.7 & 4.6 & 4.8 & 4.9 & 4.7 & 5.0 & 4.6 & 4.5 & 4.7 \\
\hline \multirow[t]{16}{*}{$50-64 y$} & & \multicolumn{3}{|c|}{$(n=3,011)$} & \multicolumn{3}{|c|}{$(n=1,265)$} & \multicolumn{3}{|c|}{$(n=1,746)$} \\
\hline & Total fat (g) & 39.9 & 38.6 & 41.1 & 46.5 & 44.5 & 48.6 & 33.2 & 32.1 & 34.3 \\
\hline & SFA (g) & 11.8 & 11.4 & 12.2 & 13.9 & 13.2 & 14.5 & 9.7 & 9.3 & 10.1 \\
\hline & MUFA (g) & 12.5 & 12.0 & 12.9 & 14.7 & 13.9 & 15.4 & 10.3 & 9.9 & 10.6 \\
\hline & PUFA (g) & 10.5 & 10.1 & 10.8 & 11.9 & 11.4 & 12.5 & 9.0 & 8.7 & 9.3 \\
\hline & n-3 FA (g) & 1.9 & 1.8 & 2.0 & 2.1 & 1.9 & 2.2 & 1.7 & 1.6 & 1.8 \\
\hline & n-6 FA (g) & 8.6 & 8.2 & 8.9 & 9.8 & 9.4 & 10.3 & 7.3 & 7.0 & 7.6 \\
\hline & Energy (kcal) & $1,920.6$ & $1,884.2$ & $1,957.1$ & $2,221.8$ & $2,168.3$ & $2,275.2$ & $1,622.6$ & $1,586.9$ & $1,658.4$ \\
\hline & $\%$ carbohydrate & 66.5 & 66.0 & 67.0 & 65.3 & 64.6 & 65.9 & 67.8 & 67.2 & 68.4 \\
\hline & $\%$ protein & 14.8 & 14.6 & 15.1 & 15.4 & 15.1 & 15.8 & 14.3 & 14.0 & 14.5 \\
\hline & $\%$ fat & 18.6 & 18.2 & 19.0 & 19.3 & 18.8 & 19.9 & 18.0 & 17.5 & 18.4 \\
\hline & $\%$ SFA & 5.5 & 5.4 & 5.7 & 5.8 & 5.6 & 6.0 & 5.3 & 5.1 & 5.5 \\
\hline & $\%$ MUFA & 5.8 & 5.6 & 5.9 & 6.0 & 5.8 & 6.2 & 5.5 & 5.3 & 5.7 \\
\hline & $\%$ PUFA & 4.9 & 4.8 & 5.0 & 5.0 & 4.8 & 5.1 & 4.8 & 4.7 & 5.0 \\
\hline & $\%$ n-3 FA & 0.9 & 0.9 & 0.9 & 0.9 & 0.8 & 0.9 & 0.9 & 0.9 & 1.0 \\
\hline & $\%$ n-6FA & 4.0 & 3.9 & 4.1 & 4.1 & 3.9 & 4.2 & 3.9 & 3.8 & 4.0 \\
\hline \multirow[t]{16}{*}{$\geq 65 y$} & & \multicolumn{3}{|c|}{$(n=2,927)$} & \multicolumn{3}{|c|}{$(n=1,296)$} & \multicolumn{3}{|c|}{$(n=1,631)$} \\
\hline & Total fat (g) & 26.6 & 25.5 & 27.7 & 31.4 & 29.9 & 33.0 & 23.1 & 21.9 & 24.2 \\
\hline & SFA (g) & 7.8 & 7.4 & 8.1 & 9.1 & 8.6 & 9.6 & 6.7 & 6.4 & 7.1 \\
\hline & MUFA (g) & 7.9 & 7.5 & 8.3 & 9.3 & 8.8 & 9.9 & 6.8 & 6.4 & 7.2 \\
\hline & PUFA (g) & 7.4 & 7.0 & 7.7 & 8.6 & 8.1 & 9.1 & 6.4 & 6.1 & 6.8 \\
\hline & n-3 FA (g) & 1.4 & 1.3 & 1.5 & 1.7 & 1.5 & 1.8 & 1.3 & 1.2 & 1.4 \\
\hline & n-6 FA (g) & 5.9 & 5.6 & 6.2 & 6.9 & 6.5 & 7.3 & 5.2 & 4.9 & 5.5 \\
\hline & Energy (kcal) & $1,599.5$ & $1,563.6$ & $1,635.3$ & $1,862.9$ & $1,814.4$ & $1,911.4$ & $1,402.1$ & $1,366.8$ & $1,437.4$ \\
\hline & $\%$ carbohydrate & 72.5 & 72.0 & 73.0 & 71.3 & 70.7 & 72.0 & 73.4 & 72.8 & 74.1 \\
\hline & $\%$ protein & 13.2 & 13.1 & 13.4 & 13.9 & 13.7 & 14.1 & 12.7 & 12.5 & 13.0 \\
\hline & $\%$ fat & 14.2 & 13.8 & 14.6 & 14.8 & 14.3 & 15.3 & 13.8 & 13.3 & 14.3 \\
\hline & $\%$ SFA & 4.2 & 4.0 & 4.3 & 4.3 & 4.2 & 4.5 & 4.1 & 3.9 & 4.2 \\
\hline & $\%$ MUFA & 4.2 & 4.0 & 4.3 & 4.3 & 4.1 & 4.5 & 4.0 & 3.8 & 4.2 \\
\hline & $\%$ PUFA & 3.9 & 3.8 & 4.0 & 4.0 & 3.9 & 4.2 & 3.8 & 3.7 & 4.0 \\
\hline & $\%$ n-3 FA & 0.8 & 0.7 & 0.8 & 0.8 & 0.7 & 0.8 & 0.7 & 0.7 & 0.8 \\
\hline & $\%$ n-6FA & 3.1 & 3.0 & 3.3 & 3.2 & 3.1 & 3.4 & 3.1 & 3.0 & 3.2 \\
\hline
\end{tabular}

SFA, saturated fatty acids; MUFA, monounsaturated fattly acids; PUFA, polyunsaturated fattly acids; FA, fattly acids.

${ }^{a}$ All analyses accounted for the complex sampling design effect and appropriate sampling weights.

b $95 \%$ confidence interval 
신뢰구간으로 제시하였다. 총 지방으로부터 얻는 에너지 비 율이 15\% 미만, 15-30\%, 30\% 초과인 대상자의 비율과 포화지방산으로부터 얻는 에너지 비율이 $7 \%$ 이상인 대상자 의 비율을 각각 성별 및 연령 그룹에 따라 제시하였다.

\section{결 과}

\section{1. 우리나라 성인의 총 지방 및 지방산 섭취량}

우리나라 성인의 총 지방 및 지방산 섭취량을 성별 및 연 령 그룹에 따라 나타낸 결과는 Table 2와 같다. 19세 이상 성인은 총 지방 $46.1 \mathrm{~g}$, 포화지방산 $14.2 \mathrm{~g}$, 단일불포화지 방산 $14.8 \mathrm{~g}$, 다중불포화지방산 $11.3 \mathrm{~g}$ 의 섭취량을 보였다. 총 지방으로부터 약 $21 \%$ 의 에너지를 얻으며, 포화지방산으
로부터 $6.4 \%$, 단일불포화지방산으로부터 $6.7 \%$, 다중불포 화지방산으로부터 $5.2 \%$ 를 얻었다. 총 지방과 지방산의 섭 취는 남녀 모두 연령이 증가함에 따라 감소하는 경향을 보였 다. 20 대 성인의 경우 총 지방으로부터 섭취하는 에너지의 비율이 $26.6 \%$, 포화지방산으로부터 섭취는 에너지의 비율 이 $8.7 \%$ 인 것에 비해 65 세 이상 노인은 $14.2 \%, 4.2 \%$ 로 나 타났다.

\section{2. 총 지방으로부터 섭취하는 에너지 비율에 대한 평가}

총 지방으로부터 얻는 에너지 비율의 분포를 성별 및 연령 그룹에 따라 평가한 결과는 Fig. 1과 같다. 19세 이상 성인 의 $30 \%$ 는 총 지방을 에너지 적정 비율 (15-30\%) 미만으 로 섭취하는 반면 $18 \%$ 는 초과하여 섭취하였다. 남녀 모두

Total

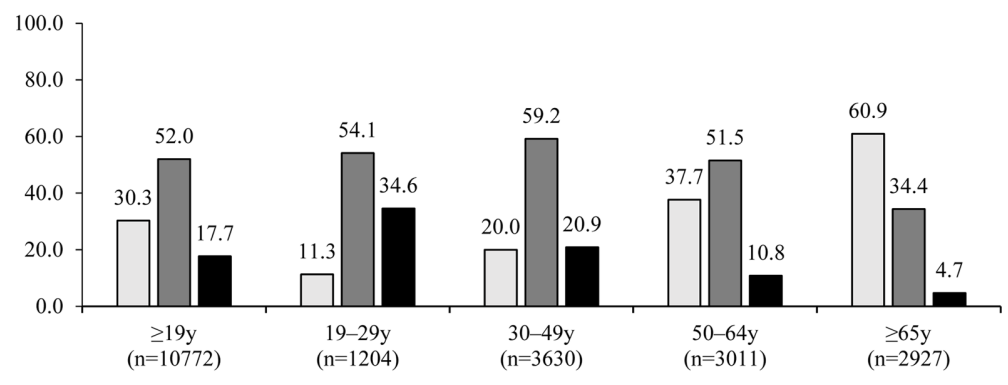

Men

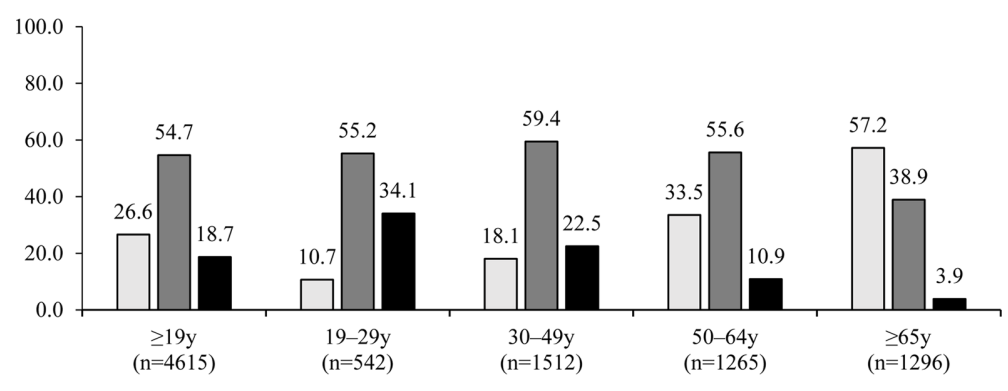

Women

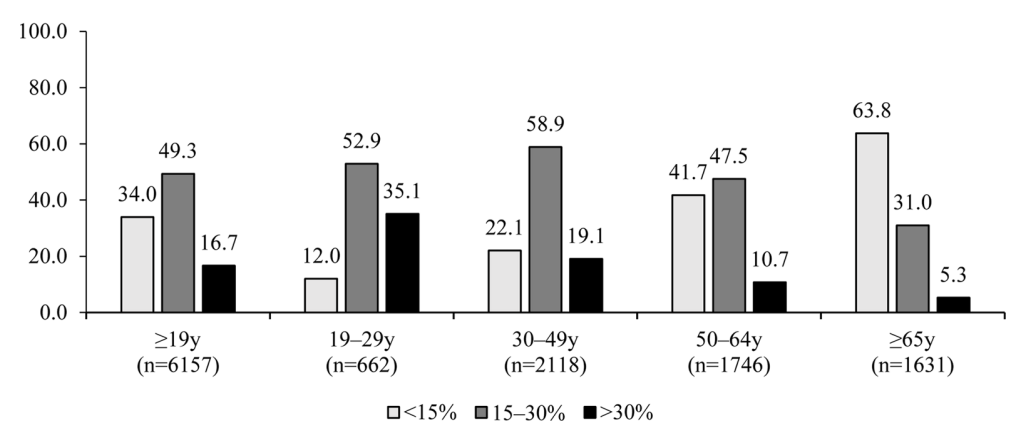

Fig. 1. Distribution of study subjects according to percentage of energy from total fat by sex and age group ${ }^{a, b}$ a All analyses accounted for the complex sampling design effect and appropriate sampling weights.

b Based on the 2015 Dietary Reference Intakes for Koreans, the Acceptable Macronutrient Distribution Range for total fat is 15-30\% in adults. 
$228 \cdot$ 우리나라 성인의 지방산 섭취 평가

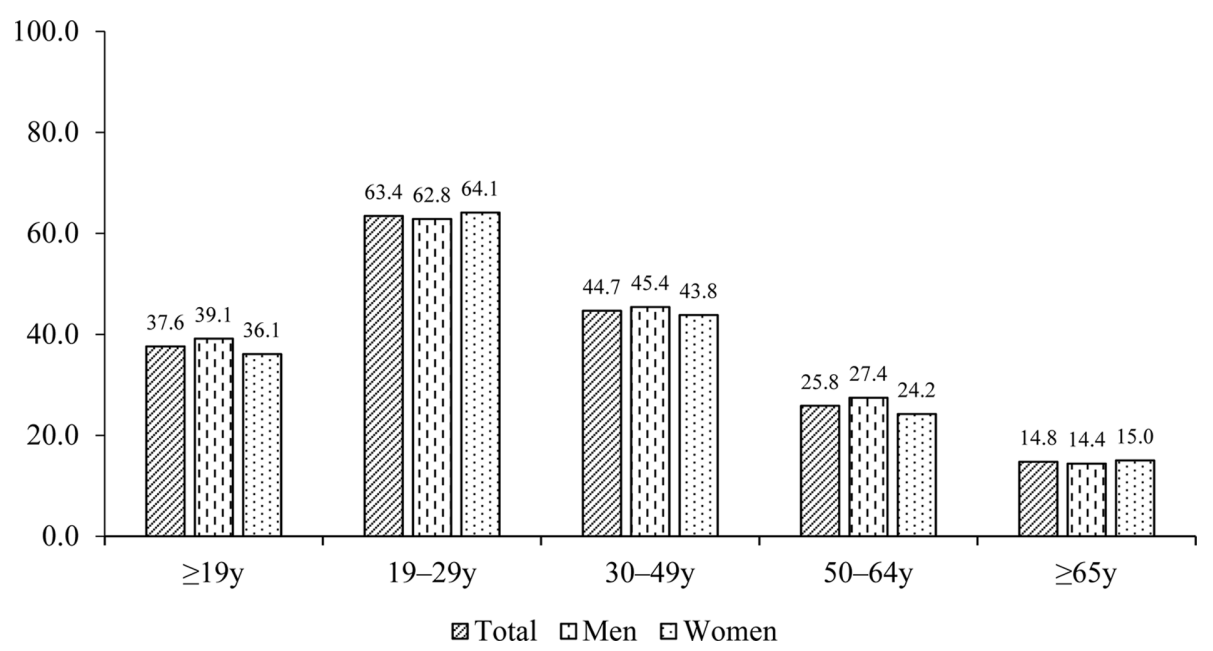

Fig. 2. Proportion of study subjects who consumed more than $7 \%$ of energy from saturated fattly acids by sex and age group ${ }^{a, b}$ a All analyses accounted for the complex sampling design effect and appropriate sampling weights.

${ }^{b}$ Based on the 2015 Dietary Reference Intakes for Koreans, the Acceptable Macronutrient Distribution Range for saturated fatty acids is less than $7 \%$ in adults.

에서 연령이 낮아질수록 적정 비율을 초과하여 섭취하는 인 구 비율이 높았고, 19-29세 그룹에서는 약 35\%가 적정 비 율을 초과하는 것으로 나타났다 (남자 $34 \%$, 여자 $35 \%$ ). 65 세 이상 노인의 $61 \%$ 가 적정 비율 미만으로 총 지방을 섭취 하고 있었으며, 총 지방으로부터 섭취하는 에너지 비율이 $30 \%$ 를 초과하는 비율은 $4.7 \%$ 였다.

\section{3. 포화지방산으로부터 섭취하는 에너지 비율에 대한 평가}

Fig. 2에는 우리나라 성인이 포화지방산으로부터 섭취하 는 에너지 비율을 성별 및 연령 그룹에 따라 나타냈다. 19세 이상 성인의 $37.6 \%$ 는 포화지방산의 에너지 적정 비율인 $7 \%$ 이상 섭취하는 것으로 나타났으며, 그 비율이 남자에서는 $39.1 \%$, 여자에서는 $36.1 \%$ 였다. 포화지방산을 에너지 적 정 비율 이상으로 섭취하는 인구 비율은 남녀 모두 연령이 증 가함에 따라 감소하였는데 19-29세 그룹에서는 $63.4 \%$, 30-49세 그룹에서는 $44.7 \%, 50-64$ 세 그룹에서는 $25.8 \%, 65$ 세 이상 그룹에서는 $14.8 \%$ 로 나타났다.

\section{고 찰}

국민건강영양조사 자료를 이용하여 2007-2015년 간 우리나라 성인의 지방산 섭취 추이를 분석한 Song 등의 연 구 [8] 와 비교할 때 최근 포화지방산의 섭취수준 변화는 주 목할 만하다. 본 연구에서 국민건강영양조사의 최신 자료인 제 7 기 자료를 분석하여 선행연구에서 보고된 이후의 섭취를 살펴보았을 때, 2016-2017년 19세 이상 성인의 지방에너 지는 총 에너지 섭취의 $20.9 \%$ 로 지속적인 증가양상을 나타
내고 있었으나 지방산의 종류에 따른 변화수준에 차이를 보 였다.

즉, 2007-2015년 간 섭취한 총 에너지에서 차지하는 포 화지방산과 다중불포화지방산의 비율은 각각 $0.6 \%$ (2007 년 4.7\%,2015년 5.3\%)와 0.5\%(2007년 4.2\%, 2015 년 $4.7 \%$ )가 증가하였으나, 이후 2년간 다중불포화지방산으 로 섭취한 에너지 (총 에너지 섭취의 $5.2 \%$ )의 증가는 $0.5 \%$ 에 그친 반면 포화지방산으로 섭취한 에너지 (총 에너지 섭취 의 $6.4 \%)$ 는 $1.1 \%$ 가 증가하여 최근 포화지방산의 섭취가 빠 른 속도로 증가하고 있음을 확인하였다. 특히 이러한 증가는 19-29세의 젊은 연령층에서 두드러지게 나타나, 최근 2년 간 다중불포화지방산의 섭취비율은 변화가 없는 반면 포화 지방산의 섭취비율은 $0.9 \%$ 가 증가하였다.

$\mathrm{WHO}$ 에서는 세계적으로 심혈관계질환이 중요한 건강문 제로 대두됨에 따라 포화지방산 섭취의 새로운 가이드라인 마련을 위한 근거를 확보하고자, 포화지방산을 단일 불포화 지방산, 다중불포화지방산, 탄수화물로 대체했을 때 혈중 지 질 수준에 미치는 효과를 연구한 무작위 실험을 체계적으로 고찰하고 회귀분석을 시행한 바 있다[14]. 체계적 문헌고찰 은 만 17세 이상의 건강에 이상을 보이지 않는 대상자에 대 해 수행된 연구 중 평행설계 (parallel design)와 교차설계 (crossover design) 연구에 한정하였으며, 포화지방산의 섭취가 다른 종류의 지방산이나 탄수화물 섭취로만 대체될 수 있도록 엄격히 식사를 통제한 연구만이 선별되었다. 선별 된 연구에서 사용된 불포화지방산은 대부분 탄소수가 18 개 인 지방산(리놀레산, 리놀렌산, 올레산)으로 구성된 것이었 다. 동 연구에서 문헌고찰을 위해 선별된 연구의 결과로 다 
중 회귀분석을 실시한 결과 탄수화물과 불포화지방산의 대 체를 통한 포화지방산 섭취의 감소는 혈중 총 콜레스테롤과 $\mathrm{LDL}-$ 콜레스테롤 수준의 감소 효과로 나타났다. 그러나 탄 수화물 섭취의 증가는 중성지방의 증가를 동반한다는 점에 서는 단일불포화지방산과 다중불포화지방산으로 대체하는 것이 유리한 것으로 분석되었으며, 가장 효과적인 것은 다중 불포화지방산으로 대체하는 것이었다. 이러한 효과는 대상 집단의 연구 시작 시점에서의 포화지방산 섭취수준에 따라 층화하여 분석하였을 때도 변함이 없었으나, 탄수화물의 종 류에 따른 효과에 대해서는 분석하지 못하였다고 보고하고 있다.

그러나 고탄수화물식이라도 식이섬유의 함량이 높은 식사 는 식이섬유의 함량이 낮은 중등도 탄수화물식에 비해 중성 지방을 포함한 혈중지질수준을 바람직한 방향으로 변화시키 는 것으로 보고되고 있다[17]. 이는 제 2 형 당뇨병 환자를 대 상으로 탄수화물과 식이섬유 섭취수준에 따른 혈당, LDL콜레스테롤, 중성지방 수준의 변화를 메타분석한 것으로 고 탄수화물 고식이섬유식에서 혈중 중성지방이 $13 \%$ 감소하 는 것으로 나타났다. 또한, 인구집단을 대상으로 한 연구에 서 포화지방산 섭취가 감소하면 보통 정제된 탄수화물이나 첨가당의 섭취가 증가하는 것이 관찰되며 [18], 단순당 섭취 와 혈중 중성지방 수준 사이에 양의 상관관계가 있다는 연구 결과가 보고 되고 있다 [19]. 따라서, 이상지질혈증 및 이와 관련된 심혈관계질환의 예방과 관리를 위해 포화지방산을 다 른 에너지 급원으로 대체하고자 할 때 대체할 에너지 급원을 바르게 권장하기 위해서는 탄수화물의 종류에 따른 효과도 반드시 고려되어야 한다.

우리나라는 곡류의 섭취가 감소하는 추세에서도 아직까지 총 에너지 중 평균 $60 \%$ 이상을 탄수화물로 섭취하는, 전통 적으로 탄수화물의 섭취가 높은 식생활 패턴을 가지고 있다. 그리고 이상지질혈증의 유병율에 있어서도 고콜레스테롤혈 증보다는 고중성지방혈증의 수준이 높은 양상을 보여왔다.

그러나 최근 이러한 경향이 크게 달라지고 있다. 2017 국 민건강통계에서는 30세 이상의 성인에 대해 2005년 추계 인구로 표준화하여 주요 만성질환의 유병율 추이를 보고하 고 있다 [20] . 이에 따르면 2007-2017년간 고중성지방혈 증은 연도에 따라 $16.4 \%-18.0 \%$ 수준에서 변동을 보이고 있으나, 고콜레스테롤혈증은 $10.7 \%$ 에서 $21.5 \%$ 로 지속적 으로 증가하고 있다. 그 결과 2017년 현재 고중성지방혈증 은 $16.4 \%$, 고콜레스테롤혈증은 $21.5 \%$ 로 고콜레스테롤혈 증의 유병율이 더 높은 상황이다.

특히 고중성지방혈증의 유병율은 성별에 따라 큰 차이를 보이며, 여성의 유병율이 $8.0 \%$ 인 것에 비해 남성은 $25.2 \%$
로 3배 이상 높다. 2017년 국민건강영양조사의 식품섭취량 조사 결과를 19 세 이상의 성인에 대해 2005년 추계인구로 표준화하였을 때, 남성은 총 에너지의 $61.8 \%$ 여성은 $63.6 \%$ 의 에너지를 탄수화물로 섭취하여 섭취수준에는 큰 차이를 보이지 않고 있다 [20]. 그러나 탄수화물의 급원으로서 과일 류의 섭취에서 남녀간 차이를 나타내는데, 남성은 총 섭취량 의 $18.4 \%$ 를 곡류로, $17.1 \%$ 를 채소류로, $7.9 \%$ 를 과일류로 섭취하고 있으며, 여성은 총 섭취량의 $18.8 \%$ 를 곡류로, $17.2 \%$ 를 채소류로, $12.0 \%$ 를 과일류로 섭취하고 있다. 두 결과를 직접 연관지어 말하기는 어려우나 고탄수화물 고식 이섬유식이 혈중 중성지방의 수준을 감소시키는 것으로 보 고한 Anderson 등의 연구 [17]에서와 같이 비슷하거나 또 는 조금 높은 수준의 탄수화물을 섭취하더라도 섭취하는 탄 수화물의 종류(전분 vs. 식이섬유)에 따라 혈중 중성지방수 준이 차이를 나타낼 수 있음을 고려할 필요가 있다.

또한 2017년 현재 성인 남성은 고위험음주를 하는 분율 이 $21 \%$ 로 $7.2 \%$ 인 여성의 3 배에 이른다[20]. 알코올 섭취 는 지단백질의 대사에 영향을 미쳐 혈중 중성지방농도를 증 가시킴으로써 고중성지방혈증을 유발시킬 수 있다[21]. 알 코올 섭취는 간에서의 지방합성을 활성화시키며, 섭취한 알 코올로부터 생성된 아세트산은 말초조직의 지방분해를 저해 한다 [22]. 보통 수준의 알코올 섭취가 심혈관 질환의 위험 을 감소시키는 것으로 보고되고 있으나 혈중 지질 중 중성지 방의 수준은 증가시킨다 [23, 24].

따라서 현재 우리나라에서 주로 남성들에게서 높은 유병 율을 보이고 있는 고중성지방혈증에 탄수화물의 질이나 음 주 습관이 미치는 영향을 밝히기 위한 잘 고안된 연구가 필 요하며, 그에 앞서 남성과 여성의 유병율 차이에 원인이 될 수 있는 식사 및 생활습관의 차이를 면밀히 분석할 필요가 있 다. 이를 바탕으로 고중성지방혈증의 예방과 관리를 위한 다 량 영양소의 적절한 섭취 지침이 마련될 수 있을 것으로 사 료된다.

한편, 우리나라 성인 인구에서 전반적으로는 총 지방 및 포 화지방의 에너지 섭취수준이 증가하고 있으나, 에너지 적정 비율의 관점에서 볼 때 연령에 따라 다른 문제를 나타내고 있 음도 주지해야 할 필요가 있다. 지방의 에너지 적정 비율 범 위에 따른 분포를 볼 때 19-64세의 연령층에서는 지방의 에너지 적정 비율을 충족하여 섭취하는 인구의 비율이 가장 높으나 연령이 높을수록 에너지 적정 비율을 초과하는 비율 은 감소하고 에너지 적정 비율에 미치지 못하는 섭취를 하는 인구의 비율이 증가하고 있다. 특히 65세 이상의 대다수가 에너지 적정 비율에 미치지 못하는 섭취를 하고 있어, 젊은 연령층과는 달리 건강을 유지하기 위해 충분한 섭취를 할 것 
을 권장할 필요가 있다.

본 연구에서 이용한 국민건강영양조사 자료는 24 시간회 상법을 통하여 하루의 섭취를 분석한 것으로 개인내변이의 영향을 크게 받기 때문에 인구집단에서 과다섭취 또는 과소 섭취 비율을 추정하는데 한계가 있다. 따라서, 본 연구에서 분석된 지방에너지의 적정 섭취비율을 초과하는 인구비율은 실제 수준보다 과대추정되었을 가능성이 높다. 그러나 인구 집단의 평균적인 섭취수준과 섭취추이의 변화를 살펴보는 데 있어서는 인구집단을 대표하는 표본자료로서 의미가 크다. 이를 통해 본 연구에서는 우리나라의 지방 섭취수준의 최근 동향을 분석하고 이와 관련 있는 만성질환의 추이와 함께 그 의미를 해석함으로써 국민건강증진을 위한 중재방안 마련의 중요한 근거자료를 제시할 수 있을 것으로 사료된다.

\section{요약 및 결론}

본 연구에서는 2016-2017년 국민건강영양조사 자료를 활용하여 우리나라 성인의 총 지방 및 지방산 섭취를 평가하 였다. 우리나라 성인은 일일 약 $46 \mathrm{~g}$ 의 총 지방을 섭취하며, 지방으로부터 섭취하는 에너지의 비율이 $21 \%$ 정도를 차지 하고 있다. 각 지방산 종류에 따른 에너지 섭취 비율은 포화 지방산 $6.4 \%$, 단일불포화지방산 $6.7 \%$, 다중불포화지방산 $5.2 \%$ 이다.

한국인 영양소 섭취 기준의 에너지 적정 비율과 비교하여 총 지방의 섭취를 평가하면, 약 $18 \%$ 의 성인이 총 지방의 적 정 비율 (15-30\%)을 초과하여 섭취하고 있으며, 19-29 세 성인의 경우는 $35 \%$ 가 적정 비율을 초과하는 것으로 나 타났다. 반면 65세 이상 노인에서는 적정 비율 미만으로 섭 취하는 인구 비율이 $61 \%$ 가량으로 나타났다.

포화지방산의 에너지 적정 비율은 $7 \%$ 미만으로 제시되어 있으며, 이와 비교하였을 때 우리나라 성인의 약 $38 \%$ 는 적 정 비율을 초과하는 섭취 수준을 보였다. 연령이 증가함에 따 라 적정 비율을 초과하는 인구 비율은 줄어드는 경향을 보이 나 19-29세 그룹의 약 63\%, 30-49세 그룹의 약 45\%는 포화지방산으로부터 $7 \%$ 이상의 에너지를 섭취하고 있었다.

현재 우리 국민의 지방 섭취수준은, 지방, 특히 포화지방 산의 높은 섭취수준과 이에 따른 심혈관계질환이 이미 중요 한 국가 보건문제로 대두되었던 서구사회에 비하면 낮은 수 준이나, 지속적으로 증가하고 있다. 특히 포화지방산으로부 터 섭취하는 에너지의 비율이 빠르게 증가하고 있다. 이는 현 재 증가하고 있는 고콜레스테롤혈증과 심장질환으로 인한 사 망을 고려할 때 포화지방산 섭취 감소를 위한 적극적인 중재 가 필요한 시점임을 시사한다. 이에 따라, 포화지방산을 대
체할 건강한 에너지 급원에 관해 올바른 정보를 제공하는 학 계의 노력과 포화지방산 섭취감소의 필요성을 적극적으로 홍 보하고, 포화지방산의 섭취 감소를 위한 개인의 노력을 지지 하는 정책적인 접근이 시급하다.

\section{ORCID}

Jae Eun Shim https://orcid.org/0000-0001-8458-9112

SuJin Song https://orcid.org/0000-0003-1871-4346

\section{References}

1. World Health Organization (WHO). Diet, nutrition and the prevention of chronic diseases: Report of a joint WHO/FAO expert consultation. WHO; 2003. WHO Technical Report Series no. 916.

2. Korea Centers for Disease Control and Prevention (KCDC), Ministry of Health and Welfare (MoHW). Current status and issues regarding chronic disease. KCDC; 2018 Dec.

3. Statistics Korea. Cause-of-death statistics in 2017 in the Republic of Korea [internet]. National Center for Health Statistics; 2018 [cited 2018 Sep 19]. Available from: http://kostat.go.kr.

4. Pot GK, Prynne CJ, Roberts C, Olson A, Nicholson SK, Whitton $\mathrm{C}$ et al. National Diet and Nutrition Survey: fat and fatty acid intake from the first year of the rolling programme and comparison with previous surveys. Br J Nutr 2012; 107(3): 405-415.

5. Li K, McNulty BA, Tiernery AM, Devlin NF, Joyce T, Leite JC et al. Dietary fat intakes in Irish adults in 2011: how much has changed in 10 years? Br J Nutr 2016; 115(10): 1798-1809.

6. Sette S, Le Donne C, Piccinelli R, Arcella D, Turrini A, Leclercq $\mathrm{C}$ et al. The third Italian national food consumption survey, INRAN-SCAI 2005-06-part 1: nutrient intakes in Italy. Nutr Metab Cardiovasc Dis 2011; 21(12): 922-932.

7. National Center for Health Statistics (NCHS). Health, United States, 2016: With chartbook on long-term trends in health. Washington, DC: NCHS; 2017.

8. Song S, Shim JE, Song WO. Trends in total fat and fatty acid intakes and chronic health conditions in Korean adults over 2007-2015. Public Health Nutr 2019; 22(8): 1341-1350.

9. Hooper L, Martin N, Abdelhamid A, Smith GD. Reduction in saturated fat intake for cardiovascular disease. Cochrane Database Syst Rev 2015; 6.

10. Hu FB, Stampfer MJ, Manson JE, Rimm E, Colditz GA, Rosner BA et al. Dietary fat intake and the risk of coronary heart disease in women. New Engl J Med 1997; 337(21): 1491-1499.

11. Jakobsen MU, O'Reilly EJ, Heitmann BL, Pereira MA, Bälter K, Fraser GE et al. Major types of dietary fat and risk of coronary heart disease: a pooled analysis of 11 cohort studies. Am J Clin Nutr 2009; 89(5): 1425-1432.

12. Mozaffarian D, Micha R, Wallace S. Effects on coronary heart disease of increasing polyunsaturated fat in place of saturated fat: a systematic review and meta-analysis of randomized controlled 
trials. PLoS Med 2010; 7(3): e1000252.

13. Wong ND. Epidemiological studies of CHD and the evolution of preventive cardiology. Nat Rev Cardiol 2014; 11(5): 276-289.

14. Mensink RP. Effects of saturated fatty acids on serum lipids and lipoproteins: A systematic review and regression analysis. Geneva: WHO; 2016.

15. Kweon S, Kim Y, Jang MJ, Kim Y, Kim K, Choi S et al. Data resource profile: the Korea National Health and Nutrition Examination Survey (KNHANES). Int J Epidemiol 2014; 43(1): 69-77.

16. The Korean Nutrition Society. Dietary reference intakes for Koreans 2015. Seoul: MoHW \& the Korean Nutrition Society; 2016.

17. Anderson JW, Randles KM, Kendall CW, Jenkins DJ. Carbohydrate and fiber recommendations for individuals with diabetes: a quantitative assessment and meta-analysis of the evidence. J Am Coll Nutr 2004; 23(1): 5-17.

18. Li Y, Hruby A, Bernstein AM, Ley SH, Wang DD, Chiuve SE et al. Saturated fats compared with unsaturated fats and sources of carbohydrates in relation to risk of coronary heart disease: a prospective cohort study. J Am Coll Cardiol 2015; 66(14): 15381548.
19. Welsh JA, Sharma A, Abramson JL, Vaccarino V, Gillespie C, Vos MB. Caloric sweetener consumption and dyslipidemia among US adults. JAMA 2010; 303(15): 1490-1497.

20. Korea Center for Disease Control and Prevention, Ministry of Health and Welfare. Korea Health Statistics 2017: Korea National Health and Nutrition Examination Survey (KNHANES VII-1). MoHW; 2018 Dec.

21. Robinson SF, Quarfordt SH. The effect of ethanol on lipoprotein metabolism. Alcohol Clin Exp Res 1981; 5(1): 101-109.

22. Siler SQ, Neese RA, Hellerstein MK. De novo lipogenesis, lipid kinetics, and whole-body lipid balances in humans after acute alcohol consumption. Am J Clin Nutr 1999; 70(5): 928-936.

23. Rimm EB, Williams P, Fosher K, Criqui M, Stampfer MJ. Moderate alcohol intake and lower risk of coronary heart disease: meta-analysis of effects on lipids and haemostatic factors. BMJ 1999; 319(7224): 1523-1528.

24. Pownall HJ, Ballantyne CM, Kimball KT, Simpson SL, Yeshurun D, Gotto AM Jr. Effect of moderate alcohol consumption on hypertriglyceridemia: a study in the fasting state. Arch Intern Med 1999; 159(9): 981-987. 